\title{
Review \\ Endocrinology and hormone therapy in breast cancer Selective oestrogen receptor modulators and downregulators for breast cancer - have they lost their way?
}

Stephen RD Johnston

Department of Medicine - Breast Unit, The Royal Marsden NHS Foundation Trust, London, UK

Corresponding author: Stephen RD Johnston, stephen.johnston@rmh.nhs.uk

Published: 6 April 2005

This article is online at http://breast-cancer-research.com/content/7/3/119

(c) 2005 BioMed Central Ltd
Breast Cancer Research 2005, 7:119-130 (DOI 10.1186/bcr1023)

also result from the drug's partial agonistic activity stimulating tumour regrowth [6].

The term 'selective oestrogen receptor modulator' (SERM) refers to the capacity of separate anti-oestrogens to exert alternative effects on various oestrogen regulated targets. Over the past $10-15$ years several strategies were employed to improve or alter the agonist/antagonist profile of tamoxifen. An understanding of structure-function relationships led to chemical modifications of tamoxifen, either by altering the side chains to produce new tamoxifen analogues such as toremifene, idoxifene, droloxifene, lasofoxifene and TAT-59; or by altering the nonsteroidal triphenylethylene ring structure of tamoxifen to produce a nonsteroidal 'fixed ring' structure such as the benzothiophene derivatives raloxifene and arzoxifene, the benzopyran derivative acolbifene, and the indole ERA923. All of these nonsteroidal anti-oestrogens have been classified as SERMs because they exhibit mixed tissue dependent agonist/antagonist activity.

At the same time the search for a 'pure anti-oestrogen' with no agonist activity and increased antagonist potency compared with tamoxifen led to the discovery of the selective oestrogen receptor downregulators (SERDs; e.g. fulvestrant). Experimental models have shown that the novel steroidal antioestrogen fulvestrant, which is devoid of agonist effects, can antagonize tamoxifen-stimulated growth, and as a treatment for hormone sensitive tumours it may delay the emergence of resistance. This led to the hope that these different structural classes of anti-oestrogens (Fig. 1) with an altered agonist/ antagonist profile may overcome this form of resistance and improve further on the efficacy of tamoxifen in treating breast cancer. Central to this approach, however, is an understanding of the molecular biology of the oestrogen receptor

$\mathrm{Al}=$ aromatase inhibitor; $\mathrm{ER}=$ oestrogen receptor; $\mathrm{LTED}=$ long-term oestrogen deprivation; PgR $=$ progesterone receptor; SERD $=$ selective oestrogen receptor downregulator; SERM = selective oestrogen receptor modulator. 


\section{Tamoxifen}<smiles>C/C=C(\c1ccccc1)C(c1ccccc1)c1ccc(OCCN(C)C)cc1</smiles>

Raloxifene

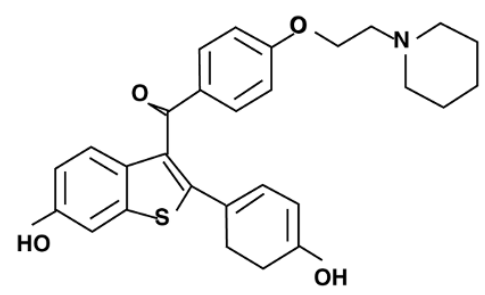

\section{Toremifene}<smiles>CNCCOc1ccc(C(=C(CCCl)c2ccccc2)c2ccccc2)cc1</smiles>

Fulvestrant

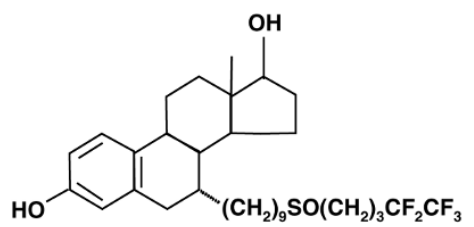

Chemical structures of anti-oestrogen compounds. Shown are the chemical structures of tamoxifen, the 'tamoxifen-like' selective oestrogen receptor modulator (SERM) toremifene, the 'fixed-ring' SERM raloxifene, and the selective oestrogen receptor downregulator (SERD) fulvestrant.

(ER) and the differential effects of various SERMs and SERDs in effectively antagonizing the action of ER.

\section{Molecular biology of the eostrogen receptor: differential effects of SERMs and SERDs}

Progress in our molecular understanding of ER function has provided insights into the differential effects of various ER ligands, including oestrogen and tamoxifen in different tissues (for review [7]). Oestrogen influences gene expression and cellular phenotype by diffusing into the cell and binding nuclear ER, which in turn activates receptor dimerization; association with various coactivator and corepressor proteins to a greater or lesser extent, respectively; and subsequent DNA binding of liganded ER within promoter regions of DNA upstream of oestrogen regulated target genes. Gene transcription is activated through two separate transactivation domains within $E R$, termed $A F-1$ in the amino-terminal $A / B$ region and $A F-2$ in the carboxyl-terminal $E$ region [8]. At its simplest level tamoxifen functions as a competitive antioestrogen to inhibit the action of oestrogen. Tamoxifen-bound ER still dimerizes and binds DNA, but the downstream effects are different as a result of the altered conformational shape of the tamoxifen-ER complex as compared with oestradiol. This results in a change in the receptor bound balance of coactivators and corepressors, such that tamoxifen-liganded ER may block gene transcription through the AF-2 domain while AF-1 mediated gene transcription may still occur [9]. This may explain the partial agonist activity of tamoxifen in addition to its ability to antagonize oestrogen regulated gene transcription (Fig. 2).
It has become clear that the molecular biology of ER is complex, and that other aspects of its function may mediate the differential ligand effects seen in response to oestrogen or tamoxifen. In addition to classical ER (now called ER- $\alpha$ ), a second ER was cloned (ER- $\beta$ ), which shares sequence homology within the DNA binding domain [10] but which differs in that AF- 1 activity is considerably less than with ER- $\alpha$ [11]. Equally ER- $\beta$ lacks much of the carboxyl-terminal $F$ domain of ER- $\alpha$, which may be an important region in determining an agonist response to tamoxifen [12]. The distribution in normal tissues of ER- $\beta$ is different from that of ER- $\alpha$, which implies a distinct physiological role, and some evidence has implicated increased ER- $\beta$ expression as a mechanism for tamoxifen resistance in breast cancer [13]. It has also been established that, in addition to the classical model of liganded ER that binds DNA at defined oestrogen response elements, other response pathways can become activated by ER. For example, AP-1 response elements regulate genes involved in cell proliferation, motility and apoptosis, and liganded ER may indirectly regulate AP-1 gene transcription through direct protein-protein interaction with AP-1 transcription factors (c-fos and c-jun). Tamoxifen was shown to be an agonist on AP-1 regulated genes with either ER- $\alpha$ or ER- $\beta$ [14], whereas oestrogen liganded with ER- $\beta$ inhibited AP-1 gene transcription [15]. Enhanced activation of AP-1 by tamoxifen may also be associated with tamoxifen resistance in models of breast cancer [16], and in tumours from breast cancer patients relapsing on tamoxifen [17]. Finally, the relative balance in a given cell type of coactivator and corepressor proteins may also determine the 

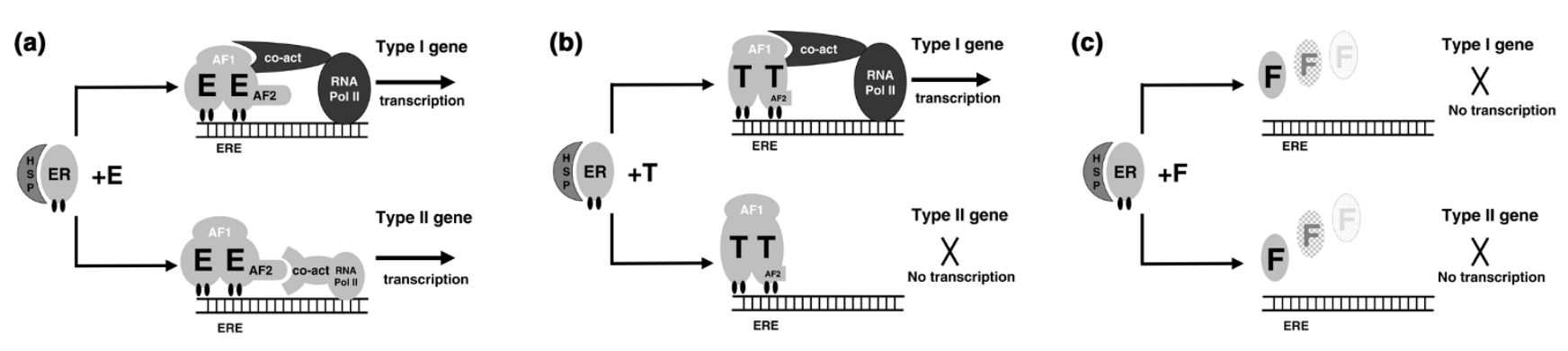

\begin{abstract}
Molecular effects of oestradiol and anti-oestrogen compounds. Shown are the molecular effects of (a) oestradiol, (b) the selective oestrogen receptor modulator (SERM) tamoxifen and (c) the selective oestrogen receptor downregulator (SERD) fulvestrant on oestrogen receptor (ER) dimerization, conformational shape and DNA binding by liganded receptor, AF1/AF2 activation, coactivator recruitment, and subsequent transcriptional activation of type I and type II ER-regulated genes. As shown in panel a, oestradiol binding to ER leads to loss of heat shock proteins (HSPs), dimerization and phosphorylation of receptors, with conformational change leading to coactivator activation at both AF1 and AF2 sites; a full agonist effect is seen. In panel b, SERM (tamoxifen) binding to ER leads to loss of HSPs, dimerization and phosphorylation of receptors, but with different specific conformational change leading to coactivator activation at AF1 only, and not at AF2 sites; therefore, a partial agonist effect is seen. As shown in panel c, SERD (fulvestrant) binding to ER leads to loss of HSPs, but lack of receptor dimerization because of altered conformational change. Thus, receptor degradation is enhanced with no activation at AF1 or AF2 sites; no agonist effect is seen. AF, activating function; E, oestradiol; ERE, oestrogen response element; F, fulvestrant; RNA Pol II, ribonucleic acid polymerase II; T, tamoxifen.
\end{abstract}

given response of ER to a particular ligand. For example, overexpression of the coactivator SRC-1 has been shown to enhance the agonist response to tamoxifen [18], whereas a reduction in the level of the corepressor $\mathrm{N}-\mathrm{CoR}$ was associated with development of tamoxifen resistance in breast cancer xenografts [19]. Thus, changes in expression of ER- $\beta$ relative to ER- $\alpha$, enhancement of the AP- 1 pathway, or a change in the balance of coactivator/corepressor proteins could all account for differential agonist/antagonist responses to anti-oestrogens both in different target tissues and human breast carcinomas.

The development of SERMs, which are structurally different from tamoxifen, has provided further insight into the biology of ER action, and created a new understanding of how modulating the structure-function interaction of ligand with ER could alter the biological effect. A crucial aspect of oestrogen-ER interaction is the complete envelopment of the steroid in a hydrophobic pocket within the ligand binding domain due to the critical positioning of a 'lid' formed by helix 12 of the ER. The position of this helix is also critical for the correct recruitment of coactivators to the AF-2 transactivation site, which allows subsequent initiation of RNA polymerase activity (Fig. 2). Occupation of the ligand-binding domain by tamoxifen, SERMs, or SERDs may result in a qualitatively different conformational shape of the liganded receptor, due to the alkylaminoethoxy side chain of the tamoxifen-like triphenylethylenes (i.e. toremifene), the different structure of the fixed ring benzothiophenes (i.e. raloxifene), or the long side chain of steroidal anti-oestrogens (i.e. fulvestrant; Fig. 1). This imparts a different positioning of the helix 12 'lid', the exact nature of which depends on the conformational shape that each anti-oestrogen imparts to the ligand ER complex [20]. As a result, the relative positioning of helix 12 may influence the likelihood of coactivator/corepressor binding, and as such determine the transcriptional response to liganded ER for a given gene. Likewise, in the endometrium tamoxifen, but not raloxifene, may have oestogenic-like effects due to recruitment or coactivators to a subset of genes, and this aspect may vary in different tissues depending on the background level of expression of coactivators such as SRC-1 [21].

These data provided a foundation for new hypotheses based on the chemical structure and structure-function relationship for each of the different SERMs/SERDs, along with the cell type and promoter specific differences in coregulator recruitment, which together may explain their differential antagonist/agonist profile observed in different tissues. Based on these characteristics, which seem to differentiate these new compounds from tamoxifen, several of the SERMs were developed for breast cancer with the expectation that they would have an improved preclinical and clinical profile (Table 1).

\section{'Tamoxifen-like' triphenylethylene SERMs}

For each of the triphenylethylene derivatives preclinical data suggested an improved antagonist/agonist profile compared with tamoxifen. This led to their clinical development in the hope that these may prove safer or more effective antioestrogens for the treatment of breast cancer compared with tamoxifen. The preclinical and clinical data were reviewed in detail elsewhere [22], but key aspects of each compound are highlighted below.

\section{Toremifene}

Toremifene's only structural difference compared with tamoxifen relates to a single chlorine atom at position 4 
Table 1

\begin{tabular}{ll} 
The ideal profile of a novel SERM in comparison with tamoxifen \\
\hline Profile & Details \\
\hline Preclinical & $\begin{array}{l}\text { Greater binding affinity for ER } \\
\text { Ability to antagonize oestrogen dependent growth of } \\
\text { breast cancer cells in vitro } \\
\text { Equal or greater inhibition of hormone-dependent } \\
\text { xenograft growth in vivo } \\
\text { Activity against tamoxifen dependent (resistant) } \\
\text { tumours } \\
\text { Delayed emergence of anti-oestrogen resistance in vivo } \\
\text { Reduced agonist effects in uterotrophic assays } \\
\text { Lack of stimulation of endometrial cancer cells in vitro/ } \\
\text { in vivo } \\
\text { Lack of DNA adduct formation } \\
\text { Prevention of bone loss in ovariectomized animals } \\
\text { Activity in hormone sensitive breast cancer, at least } \\
\quad \text { equivalent to tamoxifen } \\
\text { Increase in time to disease progression compared with } \\
\text { tamoxifen } \\
\text { Activity in tamoxifen resistant breast cancer } \\
\text { Improved side effect profile (i.e. less hot flushes) } \\
\text { No endometrial thickening/hyperplasia/cancer risk } \\
\text { Preservation of bone mineral density } \\
\text { Reduction in serum cholesterol }\end{array}$ \\
Clinical \\
\hline
\end{tabular}

ER, oestrogen receptor; SERM, selective oestrogen receptor modulator.

(Fig. 1), and as such the pharmacological profiles of these drugs are very similar. Unlike tamoxifen, toremifene was found not to be hepato-carcinogenic in preclinical models, which in part may relate to an inability of toremifene compared with tamoxifen to induce DNA adducts in rat liver [23]. Toremifene had a similar relative binding affinity for ER to tamoxifen and inhibited the growth of ER-positive breast cancer cells in vitro and in vivo [24]. However, toremifene had oestrogenic effects on endometrial cells, similar to tamoxifen [25], although it had a reduced oestrogenic effect on bone [26].

In terms of clinical efficacy, toremifene was no different to tamoxifen as first-line endocrine therapy in five large phase III randomized controlled trials (Table 2) [27-31]. A metaanalysis of these trials [32] showed an overall similar response rate for toremifene compared with tamoxifen (24\% versus $25.3 \%$ ), with no significant difference in time to disease progression or overall survival. Any potential difference in carcinogenicity, which was identified in preclinical studies, was not evaluated in any of these advanced breast cancer studies. Two adjuvant trials were initiated to compare efficacy and in particular long-term tolerability and safety in early breast cancer patients. After a median follow up of 4.4 years in the largest of these studies (1480 postmenopausal nodepositive patients) [33] there were no significant differences in relapse-free survival or tolerability, and in particular the

\section{Droloxifene}

Droloxifene (or 3-hydroxytamoxifen) had a 10-fold higher relative binding affinity for ER compared with tamoxifen, a shorter half-life, greater growth inhibition of breast cancer cells in vitro, reduced oestrogenicity in the rat uterus, and absence of DNA adduct formation [34]. However, like tamoxifen it also behaved as an oestrogen in bone, preserving bone mineral density [35]. Despite promising phase II data, in which objective responses were seen in both tamoxifen refractory and naïve settings (for review [22]), droloxifene was inferior to tamoxifen in the phase III setting and its development was stopped.

\section{Idoxifene}

Idoxifene is metabolically more stable than tamoxifen as a result of a pyrrolidino side chain, with increased binding affinity for ER due to substitution of an iodine atom at the 4 position. Preclinically, idoxifene exhibited reduced stimulation of uterine weight in various uterotrophic assays compared with tamoxifen [36], with a delay in MCF-7 xenograft outgrowth in vivo compared with tamoxifen [37]. Thus, idoxifene was developed in the hope that its reduced agonist profile in breast and gynaecologocal tissues would be an advantage over tamoxifen for breast cancer patients. However, in a randomized phase II study [38], and in two international phase III studies of idoxifene versus tamoxifen as first-line therapy in advanced breast cancer [39,40], no improvements in efficacy or safety profile over tamoxifen were demonstrated, and development of idoxifene was stopped in 2001 (Table 3).

\section{Other tamoxifen-like derivatives}

Other structural analogues of tamoxifen were synthesized, including TAT-59, which has a 10-fold higher affinity for ER than tamoxifen and was more effective at inhibiting human breast cancer xenograft growth in vivo [41]; GW5638, a carboxylic derivative, which demonstrated reduced agonist activity on the uterus in ovariectomized rats [42]; and lasofoxifene, a derivative of tetrahydronapthalene, which maintained bone mineral density in animal models [43]. None of these were developed for use in breast cancer.

\section{'Fixed ring' SERMS}

Greater optimism surrounded the profile of second- and thirdgeneration SERMs, in particular because these drugs appeared devoid of any agonist activity in the endometrium while behaving as potent anti-oestrogens in the breast that retained agonist activity in bone. The benzothiophene raloxifene is the most extensively studied SERM in this class (Fig. 1).

\section{Raloxifene}

The binding affinity of raloxifene for ER is similar to that of tamoxifen, and most of the pharmacological data showed similar activity in terms of inhibiting breast cancer cells in vitro and in vivo [44]. In preclinical models the drug maintained 
Table 2

\begin{tabular}{|c|c|c|c|c|c|c|}
\hline \multirow[b]{2}{*}{ Study [ref.] } & \multicolumn{3}{|c|}{ Toremifene } & \multicolumn{3}{|c|}{ Tamoxifen } \\
\hline & $n$ & ORR & TTP (months) & $n$ & ORR & TTP (months) \\
\hline Hayes et al. [28] & 221 & $21 \%$ & 5.6 & 215 & $19 \%$ & 5.8 \\
\hline Pyrhonen et al. [29] & 214 & $31 \%$ & 7.3 & 201 & $37 \%$ & 10.2 \\
\hline Gershanovich et al. [30] & 157 & $21 \%$ & 4.9 & 149 & $21 \%$ & 5.0 \\
\hline Nomura et al. [27] & 62 & $24 \%$ & 5.1 & 60 & $27 \%$ & 5.1 \\
\hline Milla-Santos et al. [31] & 106 & $38 \%$ & 11.9 & 111 & $32 \%$ & 9.2 \\
\hline Meta-analysis ${ }^{\mathrm{a}}[32]$ & 725 & $24.0 \%$ & 4.9 & 696 & $25.3 \%$ & 5.3 \\
\hline
\end{tabular}

Shown is a summary of clinical efficacy data from the randomised phase III trials of toremifene (40-60 mg/day) versus tamoxifen (20-40 mg/day) as first-line endocrine treatment of advanced breast cancer in postmenopausal women (oestrogen receptor status positive or unknown). aThe metaanalysis [32] was published in 1999 and included data from the first four trials [27-30], together with an unpublished small German study, but it did not include the Spanish study [31], which was published in 2001. ORR, objective response rate, including complete response and partial response; TTP, median time to disease progression.

Table 3

\section{Clinical efficacy of idoxifene versus tamoxifen}

\begin{tabular}{|c|c|c|c|c|}
\hline \multirow[b]{2}{*}{ Efficacy measure } & \multicolumn{2}{|c|}{ US phase III trial [39] } & \multicolumn{2}{|c|}{ European phase III trial [40] } \\
\hline & Tamoxifen $(n=111)$ & Idoxifene $(n=108)$ & Tamoxifen $(n=108)$ & Idoxifene $(n=112)$ \\
\hline ORR & $9 \%$ & $13 \%$ & $19 \%$ & $20 \%$ \\
\hline CBR & $39 \%$ & $34 \%$ & $48 \%$ & $38 \%$ \\
\hline TTP & 166 days & 140 days & 181 days & 127 days \\
\hline
\end{tabular}

Shown is a summary of efficacy data from two randomized double-blind phase III trials of idoxifene ( $40 \mathrm{mg} /$ day) versus tamoxifen ( $20 \mathrm{mg} / \mathrm{day})$ as first-line therapy in advanced/metasatic breast cancer. CBR, percentage of patients with either objective response or stable disease for 6 months or longer; ORR, percentage of patients with an objective response, including complete response and partial response; TTP, median time to disease progression.

bone mineral density but had significantly less oestrogenic activity on endometrial cells than did tamoxifen and could inhibit tamoxifen-stimulated endometrial cancer growth in vivo [45]. Raloxifene was not developed as an anti-oestrogen for breast cancer, and few data exist on the activity of raloxifene in patients with advanced disease (for review [22]). However, during the development of raloxifene for use in osteoporosis it was found to reduce significantly the incidence of breast cancer (in particular ER-positive tumours) in postmenopausal women by $76 \%$ (95\% confidence interval 56-87\%), without any increase in endometrial thickening or risk to the gynaecological tract [46]. This suggested that raloxifene could represent a safer SERM for use in chemoprevention a theme that has been developed further (see below).

\section{Arzoxifene}

Arzoxifene is a benzothiophene analogue; it is a more potent anti-oestrogen, with an improved SERM profile and greater anticancer efficacy as compared with raloxifene [47-49]. Clinical efficacy was reported in a phase II study in hormone- sensitive advanced breast cancer [50]. A second phase II trial compared two doses in 63 tamoxifen-resistant patients, and separately in 49 patients with hormone-sensitive disease [51]. Response rates were low in the tamoxifen-resistant patients $(10 \%$ for $20 \mathrm{mg}, 3 \%$ for $50 \mathrm{mg}$ ). In contrast, a response rate of $30 \%$ was seen with $20 \mathrm{mg}$ arzoxifene in the hormone-sensitive group, with a further $17 \%$ having stable disease. The response rate for the $50 \mathrm{mg}$ dose was somewhat lower $(8 \%)$, and $20 \mathrm{mg}$ dose arzoxifene was taken forward into a large multicentre phase III trial against tamoxifen as first-line therapy.

\section{Acolbifene}

EM-800 (SCH-57050) is an orally active prodrug of the active benzopyrene derivative acolbifene (EM-652), a socalled 'pure' nonsteroidal anti-oestrogen [52]. Preclinically, the binding affinity of acolbifene for ER was significantly greater than that of oestradiol, tamoxifen, raloxifene, or fulvestrant, and in vitro acolbifene was more effective than 4-hydroxytamoxifen or fulvestrant at inhibiting oestradiol induced breast 
cancer cell proliferation [53]. In vivo, acolbifene was devoid of any agonist activity in an immature rat uterotrophic assay and on mouse endometrial tissues [54,55]. In an in vivo ZR75-1 breast cancer xenograft model in ovariectomized mice acolbifene had no agonist effects on tumour growth, and was more effective at inhibiting oestrone-stimulated tumour growth than were five other tested anti-oestrogens (tamoxifen, toremifene, idoxifene, GW-5638 and raloxifene), with complete regressions seen in $65 \%$ of acolbifene treated tumours [56]. Likewise EM-800 (the oral precursor of the active metabolite acolbifene) was 30 -fold more potent than tamoxifen at inhibiting uterine weight and reducing uterine/ vaginal ER expression [57]. In addition, studies have shown that EM-800 can prevent bone loss in the ovariectomized rat and lower serum cholesterol levels [58].

In terms of clinical development, a phase II study of EM-800 (20 mg or $40 \mathrm{mg}$ ) was undertaken in 43 postmenopausal women who had progressed on tamoxifen either in the metastatic or adjuvant setting [59]. There was one complete response and four partial responses (response rate 12\%), with a median duration of response of 8 months. An additional seven (16\%) patients had stable disease for longer than 6 months. These results in patients with defined tamoxifen-resistant disease are in contrast to those observed with other SERMs described above, for which partial crossresistance with tamoxifen occurred, and a randomized phase III study in patients who had failed tamoxifen was initiated that will compare the efficacy of EM-800 with the aromatase inhibitor (Al) anastrozole. These data imply that as a 'pure' anti-oestrogen devoid of agonist activity, EM-800 may have an important different mechanism of action to that of other SERMs, and indeed may possess greater similarities to the steroidal anti-oestrogen fulvestrant (see below) than to the other SERMs described above.

\section{ERA-923}

The anti-oestrogen zindoxifene (D16726) is a 2-phenylindole structure that was previously shown to have oestrogenic activity in the uterus [60] but was inactive in a breast cancer trial [61]. By making rigid the alkylamino side chain, similar to the structure of raloxifene and EM-800, a new indole SERM called ERA-923 was created that was devoid of uterotrophic activity in immature rats when compared with raloxifene and ZK119010 [62]. ERA-923 had an improved preclinical profile in breast cancer experimental models compared with tamoxifen and raloxifene, and MCF-7 cells that are resistant to tamoxifen retain complete sensitivity to ERA-923 both in vitro and in vivo [63]. Unlike tamoxifen, droloxifene and raloxifene, ERA923 was not uterotrophic in immature rats or ovariectomized mice. Following initial safety studies in healthy volunteers [64], clinical trials of ERA-923 as second-line therapy were initiated in 100 ER-positive patients with tamoxifen resistant metastatic breast cancer, together with proposals for trials in ER-positive hormone sensitive metastatic breast cancer as

\section{Role of SERMs in chemoprevention: biomarker studies}

Although none of the SERMs outlined above has proved superior in efficacy to tamoxifen in the treatment of established breast cancer, the ability of SERMs to prevent the development of ER-positive breast cancer perhaps remains the greatest opportunity for these drugs to have a major impact on the disease. The evidence that both tamoxifen and raloxifene can prevent the development of breast cancer has provided 'proof of principle' for endocrine intervention as an important manipulation for women at risk for developing breast cancer $[3,46,65]$. However, important questions remain in the prevention setting, namely the identification of those women who are most likely to benefit from such an intervention, the most appropriate risk parameters to be used and, in particular, the safest and most effective SERM to utilize in this setting. Tamoxifen may reduce breast cancer incidence by $48 \%$ in an at-risk population, but it is associated with an increased risk for endometrial cancer and thrombotic events [3]. In contrast, raloxifene yielded an apparent greater risk reduction in breast cancer incidence with a reduced risk for endometrial cancer, albeit in a different population of women who were at risk for osteoporosis $[46,65]$. The current Study of Tamoxifen And Raloxifene (STAR) chemoprevention trial is comparing the effects of raloxifene with those of tamoxifen with the anticipation that efficacy in risk reduction may be somewhat similar, but that the toxicity profile in terms of gynaecological problems may be better for raloxifene than for tamoxifen [66].

The development of SERMs as chemoprevention agents with an even better efficacy and improved toxicity profile over tamoxifen or raloxifene remains an important goal. However, conducting large prevention studies in 20,000 women or more over $10-15$ years in order to generate results is increasingly expensive and inefficient. An alternative approach to identify novel SERM candidates for chemoprevention is to conduct short-term phase IA/IB preoperative biomarker modulation studies in women with newly diagnosed primary breast cancer. Changes in the proportion of proliferating tumour cells (as indicated by Ki-67) in ER-positive primary breast cancer has been shown to correlate with clinical response following treatment with tamoxifen [67], and more recently a greater reduction in Ki-67 after 2 weeks was observed in patients treated with the Al anastrazole than with tamoxifen [68], which is analogous to the improved outcome seen in the large scale Arimidex, Tamoxifen, Alone or in Combination (ATAC) adjuvant trial [69]. This has also been studied in randomized controlled trials in primary breast cancer with different doses of tamoxifen [70], and with the tamoxifen-like SERM idoxifene [71], raloxifene [72] and more recently arzoxifene [73]. In the placebo-controlled studies of idoxifene and raloxifene, short-term treatment for 2 weeks was associated with mean $35 \%$ and $21 \%$ reductions in $\mathrm{Ki}$ 67 , respectively, as compared with a $6-7 \%$ mean increase for placebo. In the recent study with arzoxifene, changes in 
proliferation indices in 58 women were not statistically different from placebo control because of the confounding factor of stopping hormone replacement therapy before study entry, which was not allowed in the other studies. Similar clinical studies may be warranted with the two new SERMs acolbofene and lasofoxifene, given that they appear to be potent anti-oestrogens in the breast, pro-oestrogenic in the bone, and devoid of the unwanted uterotrophoic effects seen with tamoxifen. In addition, experimental studies in carcinogeninduced mammary carcinoma in rats have shown that novel SERMs such as acolbifene [74] and arzoxifene [75] can both effectively prevent mammary cancer development.

Such biomarker data strongly support the further clinical development in the chemoprevention setting of these novel SERMs that have antiproliferative effects on breast tissue and reduced agonist effects on the gynaecological tract, but that remain protective of bone mass. Many may feel that the existing experimental and early clinical studies provide sufficient supportive data to merit clinical trials in the chemoprevention setting, albeit that such studies remain large scale, time consuming and expensive. The next step will be to develop risk algorithms to identify those women who have the most to gain from such an intervention, at whom the next generation of chemoprevention trials with a novel SERM that is safer than tamoxifen could be specifically targeted.

\section{SERDs}

\section{Mechanism of action}

SERDs are distinguishable from tamoxifen and other SERMs, both pharmacologically and in terms of their molecular activity. Although both classes of agent mediate their effects through the ER, they differ significantly in their interaction with $\mathrm{ER}$ and the subsequent downstream effects. The steroidal anti-oestrogens bind to the ER but, because of their long bulky side chains at the $7 \alpha$ and $11 \beta$ positions, receptor dimerization appears to be sterically hindered [76]. There is evidence that ER turnover is increased and nuclear localization is disrupted, with a concomitant reduction in the number of detectable ER molecules in the cell both in vitro and in vivo. This is in marked contrast to the stable or increased levels of ER expression associated with tamoxifen and other related SERMs [77]. Experimental studies suggest that, as a consequence of ER downregulation, ER-mediated transcription is completely attenuated due to inactivation of $\mathrm{AF}-1$ and AF-2, with complete suppression of oestrogen dependent gene expression (Fig. 2c).

The preclinical characteristics of fulvestrant, which define this compound as a SERD devoid of oestrogen-like activity, have been extensively reviewed [78]. These include an affinity for the ER approximately 100 times that of tamoxifen, the specific absence of oestrogen-like activity on the uterus, and the capacity to block completely the stimulatory activities of both oestrogens and anti-oestrogens like tamoxifen with partial agonist activity. The absence of oestrogenic activity has important consequences for the development of resistance, which can limit the effectiveness of long-term tamoxifen therapy. In vitro studies demonstrate that tamoxifen-resistant breast cancer cell lines remain sensitive to growth inhibition by fulvestrant [79], and that in vivo tamoxifen-resistant tumors remain sensitive to fulvestrant [80]. Taken collectively, these data suggest that fulvestrant may be a more effective oestrogen antagonist than tamoxifen that is able to produce a longer response in animal models.

\section{Clinical studies of fulvestrant}

The clinical efficacy of fulvestrant has been compared with those of tamoxifen and anastrazole in postmenopausal women with breast cancer. Some of the first clinical data came from a short-term preoperative study conducted in 201 women with operable breast cancer in which the biological effects of fulvestrant were compared with those of tamoxifen [81]. A dose-dependent reduction in the levels of ER and progesterone receptor $(\mathrm{PgR})$ expression was observed across three doses of fulvestrant (50, 125 and $250 \mathrm{mg}$ ) administered intramuscularly for 14-21 days before surgery, compared with placebo or tamoxifen. At all three doses fulvestrant reduced proliferation as measured by Ki67 labelling index [82]. These clinical data confirmed that fulvestrant acts as an ER downregulator, with clear antioestrogenic and antiproliferative activity. Furthermore, the effect on PgR provided evidence of a more complete blockade of this ER-dependent pathway compared with tamoxifen, which increased PgR levels because of its partial agonist activity.

The efficacy of fulvestrant in tamoxifen-resistant breast cancer was first demonstrated in a small phase II trial conducted in 19 patients with tamoxifen-refractory disease. Thirteen patients (69\%) achieved clinical benefit, with a median duration of 25 months, and with seven patients demonstrating a partial response and six patients stable disease [83]. These data in tamoxifen-resistant disease are in stark contrast to those with the SERMs outlined above, where crossresistance with tamoxifen was invariably shown. Two phase III studies then compared the efficacy and tolerability of fulvestrant (250 mg monthly) with anastrozole in postmenopausal women whose disease had progressed on or after prior adjuvant endocrine therapy $[84,85]$. The median time to disease progression was numerically longer with fulvestrant than with anastrozole for both trials, with a longer duration of response observed in the North American trial [84]. Fulvestrant was also well tolerated and is the first antioestrogen reported to be at least as effective as a new generation Al, unlike the trials with the tamoxifen-like or benothiophene SERMs outlined above.

More recently, data from a multinational randomized doubleblind study comparing fulvestrant $(250 \mathrm{mg}$ monthly, intramuscular) with tamoxifen ( $20 \mathrm{mg} /$ day, oral) as first-line therapy in metastatic breast cancer were reported [86]. The study 
Table 4

\begin{tabular}{|c|c|c|c|c|}
\hline Study [ref.] & Treatment (setting) & Prior systemic treatments & $\begin{array}{l}\text { Number of } \\
\text { patients }\end{array}$ & $\begin{array}{c}\text { Clinical } \\
\left.\text { benefita }^{(} \%\right)\end{array}$ \\
\hline Perey et al. [93] & Fulvestrant (third line) & Include tamoxifen and Als & 67 & 28 \\
\hline Ingle et al. [92] & Fulvestrant (second and third line) & Prior nonsteroidal Als, and tamoxifen in $79 \%$ of patients & 77 & 29 \\
\hline $\begin{array}{l}\text { Petruzelka and } \\
\text { Zimovjanova [94] }\end{array}$ & Fulvestrant (second to fifth line) & $\begin{array}{l}\text { Include nonsteroidal Als, adjuvant tamoxifen, and } \\
\text { goserelin formestane }\end{array}$ & 44 & 52 \\
\hline Franco et al. [91] & $\begin{array}{l}\text { Fulvestrant (mean prior endocrine } \\
\text { therapies }=3.4 \text { ) }\end{array}$ & $\begin{array}{l}\text { Include nonsteroidal Als, tamoxifen, megestrol acetate, } \\
\text { exemestane, and chemotherapy }\end{array}$ & 42 & 19 \\
\hline Steger et al. [95] & Fulvestrant (second to fifth line) & $\begin{array}{l}\text { Include nonsteroidal Als, tamoxifen, exemestane, } \\
\text { goserelin, and formestane }\end{array}$ & 88 & 57 \\
\hline
\end{tabular}

Phase II clinical trials with fulvestrant following disease progression on prior endocrine therapy with aromatase inhibitors (Als) are summarized. ${ }^{a}$ Clinical benefit included patients who had a complete response, partial response, or stable disease for 24 weeks or longer.

randomized a total of 587 postmenopausal women with metastatic breast cancer who were ER and/or PgR positive or in whom receptor status was unknown, and at a median follow up of 14.5 months there was no significant difference between the fulvestrant and tamoxifen groups in terms of time to progression in the whole population (median time to progression: 6.8 months versus 8.3 months, respectively; $P=0.088$ ). However, there was a significant difference in time to treatment failure in favour of tamoxifen $(P=0.026)$, with the median being 5.9 months for fulvestrant and 7.8 months for tamoxifen. These were unexpected findings that were not obviously explained by imbalance in patient groups, failure to administer intramuscular injections correctly, or undue toxicity. The separation of the Kaplan-Meier curves for time to progression occurred almost immediately and was most pronounced at 3 months, suggesting a higher rate of early progression in the fulvestrant group. Pharmacokinetic studies have shown that accumulation of the drug may take 3-6 months to reach steady state plasma levels [87].

\section{New clinical directions for SERDs}

The clinical scenario has shifted somewhat with the recent pre-eminence of the Als as the first-line endocrine therapy of choice both in the metastatic and, increasingly, in the adjuvant setting [69]. As such, there is a need to establish which endocrine agent and sequence is most effective in the post-Al setting. In vitro, long-term oestrogen deprivation (LTED) is a situation analogous to that caused by long-term $\mathrm{Al}$ treatment and subsequent $\mathrm{Al}$ resistance, and is associated with an adaptive increase in ER expression and intracellular signalling that results in hypersensitivity to low oestradiol levels $[88,89]$. It is unclear whether tamoxifen or other related SERMs will be effective in this setting given their partial agonist effects, which may be more pronounced in cells that contain these adaptive changes in ER signalling. In contrast, fulvestrant has no agonist activity and has been shown to be more effective than tamoxifen in model systems of both LTED in vivo [90]. Encouraging clinical data were reported for fulvestrant following progression on Als in five small phase II studies (Table 4), with clinical benefit seen in 19-52\% patients [91-95]. At present two large phase III trials (EFECT and SoFEA) are assessing the true benefit of using a SERD in this setting by comparing the efficacy of fulvestrant with that of the steroidal aromatase inactivator exemestane, which has demonstrated some partial non-cross-resistance with either letrozole or anastrazole; if positive, these studies may help to define the optimal role for fulvestrant in ER-positive postmenopausal metastatic breast cancer [96].

At present, no studies are being conducted to investigate the benefit of fulvestrant in the adjuvant setting. Clinical studies combining fulvestrant with various signal transduction modulators are ongoing, including trastuzumab (Herceptin), EGFR (epidermal growth factor receptor) tyrosine kinase inhibitors, and farnesyltransferase inhibitors. These trials are working on the premise that complete ER blockade combined with effective signal transduction blockade of growth factor pathways may abrogate resistance mechanisms and provide greater control of cancer cells. It also remains to be seen whether two new orally bioavailable pure anti-oestrogens (SR16234 and ZK191703) will have equivalent or superior potency in patients to intramuscularly administered fulvestrant.

\section{Conclusion}

The search for a better version of tamoxifen for the treatment and prevention of breast cancer has yielded many compounds of potential interest, but none has replaced tamoxifen in the clinical arena, despite all the effort involved; as such, many may feel that SERMs and SERDs have lost their way. The reality in the treatment of breast cancer is that they have been surpassed by the third generation Als, which have shown better tolerability than tamoxifen, with substantial gains in efficacy both in the advanced and adjuvant settings. However, this change in the treatment sequence has created 
This article is part of a review series on Endocrinology and hormone therapy in breast cancer, edited by James N Ingle and V Craig Jordan.

Other articles in the series can be found online at http://breast-cancer-research.com/articles/ review-series.asp?series=bcr_endocrinology

new challenges for development of novel endocrine therapies. It is possible that SERMs that retain a small partial agonist activity may or may not be effective in tumours that become resistant/hypersensitive to low oestradiol levels induced by LTED. In contrast, this may be an ideal opportunity for the SERD fulvestrant to demonstrate its unique endocrine activity because of its ability to downregulate the hypersensitive and activated ER present in LTED-resistant tumour cells; ongoing clinical trials in advanced disease will determine whether this preclinical promise holds forth. As for SERMs, although their clinical development may have fallen on stony ground to date, if nothing else they have given us a new opportunity to improve our understanding of the complex molecular biology of ER signalling in breast and other tissues. Their clinical resurgence may still occur in the long-term chemoprevention setting, where they could deliver an improved safety profile compared with tamoxifen, combined with effective risk reduction. SERMs may still have an impact to make, and so their development is not yet over.

\section{Competing interests}

SRDJ has received research support in the past from AstraZeneca and from SmithKline Beecham.

\section{References}

1. Cole MP, Jones CT, Todd ID: A new anti-oestrogenic agent in late breast cancer. An early clinical appraisal of $\mathrm{ICl} 46474 . \mathrm{Br} J$ Cancer 1971, 25:270-275.

2. Early Breast Cancer Trialists Group: Tamoxifen for early breast cancer: an overview of the randomised trials. Early Breast Cancer Trialists' Collaborative Group. Lancet 1998, 351:1451-1467.

3. Fisher B, Costantino JP, Wickerham DL, Redmond CK, Kavanah M, Cronin WM, Vogel V, Robidoux A, Dimitrov N, Atkins J, et al.: Tamoxifen for prevention of breast cancer: report of the National Surgical Adjuvant Breast and Bowel Project P-1 Study. J Natl Cancer Inst 1998, 90:1371-1388.

4. Jordan VC: The development of tamoxifen for breast cancer therapy. In Long-term Tamoxifen Treatment for Breast Cancer. Edited by Jordan VC. Madison: University of Wisconsin Press; 1994:3-26.

5. Fisher B, Costantino JP, Redmond CK, Fisher ER, Wickerham DL, Cronin WM: Endometrial cancer in tamoxifen-treated breast cancer patients: findings from the National Surgical Adjuvant Breast and Bowel Project (NSABP) B-14. J Natl Cancer Inst 1994, 86:527-537.

6. Johnston SR: Acquired tamoxifen resistance in human breast cancer: potential mechanisms and clinical implications. Anticancer Drugs 1997, 8:911-930.

7. Johnston SR, Dowsett $M$ : Aromatase inhibitors for breast cancer: lessons from the laboratory. Nat Rev Cancer 2003, 3: 821-831.

8. Kumar V, Green S, Stack G, Berry M, Jin JR, Chambon P: Functional domains of the human estrogen receptor. Cell 1987, 51: 941-951.
9. Tzukerman MT, Esty A, Santiso-Mere D, Danielian P, Parker MG, Stein RB, Pike JW, McDonnell DP: Human estrogen receptor transactivational capacity is determined by both cellular and promoter context and mediated by two functionally distinct intramolecular regions. Mol Endocrinol 1994, 8:21-30.

10. Kuiper GGJM, Enmark E, Pelto-Huikko M, Nilsson S, Gustafsson $\mathrm{J}-\mathrm{A}$ : Cloning of a novel estrogen receptor expressed in rat prostate and ovary. Proc Natl Acad Sci USA 1996, 93:59255930.

11. Cowley SM, Parker MG: A comparison of transcriptional activation by ER alpha and ER beta. J Steroid Biochem Mol Biol 1999, 69:165-175.

12. Montano MM, Muller V, Trobaugh A, Katzenellenbogen BS: The carboxy-terminal $F$ domain of the human estrogen receptor: role in the transcriptional activity of the receptor and the effectiveness of antiestrogens as estrogen antagonists. Mol Endocrinol 1995, 9:814-825.

13. Speirs V, Parkes AT, Kerin MJ, Walton DS, Carleton PJ, Fox JN, Atkin SL: Coexpression of estrogen receptor alpha and beta: poor prognostic factors in human breast cancer? Cancer Res 1999, 59:525-528.

14. Webb P, Lopez GN, Uht RM, Kushner PJ: Tamoxifen activation of the estrogen receptor/AP-1 pathway: potential origin for the cell-specific estrogen-like effects of antiestrogens. Mol Endocrinol 1995, 9:443-456.

15. Paech K, Webb P, Kuiper GG, Nilsson S, Gustafsson J, Kushner PJ, Scanlan TS: Differential ligand activation of estrogen receptors ERalpha and ERbeta at AP1 sites. Science 1997, 277:1508-1510.

16. Schiff R, Reddy P, Coronado E, Osborne CK: Development of tamoxifen-stimulated growth in-vivo is associated with changes in AP-1 activity. Breast Cancer Res Treat 1997, 46:A347.

17. Johnston SR, Lu B, Scott GK, Kushner PJ, Smith IE, Dowsett M, Benz CC: Increased activator protein-1 DNA binding and c-Jun NH2-terminal kinase activity in human breast tumors with acquired tamoxifen resistance. Clin Cancer Res 1999, 5:251256.

18. Smith CL, Nawaz Z, O'Malley BW: Coactivator and corepressor regulation of the agonist/antagonist activity of the mixed antiestrogen, 4-hydroxytamoxifen. Mol Endocrinol 1997, 11: 657-666.

19. Lavinsky RM, Jepsen K, Heinzel T, Torchia J, Mullen TM, Schiff R, Del-Rio AL, Ricote M, Ngo S, Gemsch J, et al.: Diverse signaling pathways modulate nuclear receptor recruitment of $\mathrm{N}-\mathrm{CoR}$ and SMRT complexes. Proc Natl Acad Sci USA 1998, 95:29202925.

20. Brzozowski AM, Pike ACW, Dauter Z, Hubbard RE, Bonn T, Engstrom O, Ohman L, Greene GL, Gustafsson J-A, Carlquist M: Molecular basis of agonism and antagonism in the oestrogen receptor. Nature 1997, 389:753-758.

21. Shang $Y$, Brown M: Molecular determinants for the tissue specificity of SERMs. Science 2002, 295:2465-2468.

22. Johnston SR: Endocrine manipulation in advanced breast cancer: recent advances with SERM therapies. Clin Cancer Res 2001, Suppl:4376s-4387s; discussion: 4411s-4412s.

23. Hard GC, latropoulos MJ, Jordan K, Radi L, Kaltenberg OP, Imondi AR, Williams GM: Major difference in the hepatocarcinogenicity and DNA adduct forming ability between toremifene and tamoxifen in female $\mathrm{Crl:CD(BR)}$ rats. Cancer Res 1993, 53:4534-4541.

24. Robinson SP, Jordan VC: Antiestrogenic action of toremifene on hormone-dependent, -independent, and heterogeneous breast tumor growth in the athymic mouse. Cancer Res 1989, 49:1758-1762.

25. O'Regan RM, Cisneros A, England GM, MacGregor Jl, Muenzner HD, Assikis VJ, Bilimoria MM, Piette M, Dragan YP, Pitot HC, et al.: Effects of the antiestrogens tamoxifen, toremifene, and $\mathrm{ICI}$ 182,780 on endometrial cancer growth. J Natl Cancer Inst 1998, 90:1552-1558.

26. Marttunen MB, Hietanen $P$, Tiitinen A, Ylikorkala O: Comparison of effects of tamoxifen and toremifene on bone biochemistry and bone mineral density in postmenopausal breast cancer patients. J Clin Endocrinol Metab 1998, 83:1158-1162.

27. Nomura Y, Tominaga T, Abe O, Izuo M, Ogawa N: Clinical evaluation of NK 622 (toremifene citrate) in advanced or recurrent breast cancer: a comparative study by a double blind method 
with tamoxifen [in Japanese]. Gan To Kagaku Ryoho 1993, 20: 247-258.

28. Hayes DF, Van Zyl JA, Hacking A, Goedhals L, Bezwoda WR, Mailliard JA, Jones SE, Vogel CL, Berris RF, Shemano I, et al:: Randomized comparison of tamoxifen and two separate doses of toremifene in postmenopausal patients with metastatic breast cancer. J Clin Oncol 1995, 13:2556-2566.

29. Pyrhonen S, Valavaara R, Modig H, Pawlicki M, Pienkowski T, Gundersen S, Bauer J, Westman G, Lundgren S, Blanco G, et al:: Comparison of toremifene and tamoxifen in post-menopausal patients with advanced breast cancer: a randomized doubleblind, the 'nordic' phase III study. Br J Cancer 1997, 76:270277.

30. Gershanovich M, Garin A, Baltina D, Kurvet A, Kangas L, Ellmen J: A phase III comparison of two toremifene doses to tamoxifen in postmenopausal women with advanced breast cancer. Eastern European Study Group. Breast Cancer Res Treat 1997, 45:251-262.

31. Milla-Santos A, Milla L, Rallo L, Solano V: Phase III randomized trial of toremifene vs tamoxifen in hormonodependant advanced breast cancer. Breast Cancer Res Treat 2001, 65: 119-124.

32. Pyrhonen S, Ellmen J, Vuorinen J, Gershanovich M, Tominaga T, Kaufmann M, Hayes DF: Meta-analysis of trials comparing toremifene with tamoxifen and factors predicting outcome of antiestrogen therapy in postmenopausal women with breast cancer. Breast Cancer Res Treat 1999, 56:133-143.

33. Holli K: Tamoxifen versus toremifene in the adjuvant treatment of breast cancer. Eur J Cancer 2002, Suppl 6:S37-S38

34. Hasmann M, Rattel B, Loser R: Preclinical data for droloxifene. Cancer Lett 1994, 84:101-116.

35. Ke HZ, Simmons HA, Pirie CM, Crawford DT, Thompson DD: Droloxifene, a new estrogen antagonist/agonist, prevents bone loss in ovariectomized rats. Endocrinology 1995, 136: 2435-2441

36. McCague R, Leclerq G, Legros N, Goodman J, Blackburn GM, Jarman M, Foster AB: Derivatives of tamoxifen; dependence of antiestrogenicity on the 4-substituent. J Med Chem 1989, 32: 2527-2533.

37. Johnston SR, Riddler S, Haynes BP, A'Hern R, Smith IE, Jarman $M$, Dowsett $M$ : The novel anti-oestrogen idoxifene inhibits the growth of human MCF-7 breast cancer xenografts and reduces the frequency of acquired anti-oestrogen resistance. Br J Cancer 1997, 75:804-809.

38. Johnston SR, Gumbrell LA, Evans TR, Coleman RE, Smith IE, Twelves CJ, Soukop M, Rea DW, Earl HM, Howell A, et al.: A Cancer Research (UK) randomized phase II study of idoxifene in patients with locally advanced/metastatic breast cancer resistant to tamoxifen. Cancer Chemother Pharmacol 2004, 53: 341-348.

39. Arpino G, Nair Krishnan M, Doval Dinesh C, Bardou VJ, Clark GM, Elledge RM: Idoxifene versus tamoxifen: a randomized comparison in postmenopausal patients with metastatic breast cancer. Ann Oncol 2003, 14:233-241.

40. Johnston SRD, Gorbunova V, Lichinister M, Manikas G, Koralewski P, Pluznaska A, Garin A, Harvey E: A multicentre double-blind randomised phase III trial of idoxifene versus tamoxifen as first-line endocrine therapy for metastatic breast cancer [abstract]. Proc Am Soc Clin Oncol 2001, 20:29a (A113).

41. Toko T, Sugimoto Y, Matsuo K, Yamasaki R, Takeda S, Wierzba K, Asao T, Yamada Y: TAT-59, a new triphenylethylene derivative with antitumor activity against hormone-dependent tumors. Eur J Cancer 1990, 26:397-404.

42. Willson TM, Norris JD, Wagner BL, Asplin I, Baer P, Brown HR, Jones SA, Henke B, Sauls $\mathrm{H}$, Wolfe $\mathrm{S}$, et al.: Dissection of the molecular mechanism of action of GW5638, a novel estrogen receptor ligand, provides insights into the role of estrogen receptor in bone. Endocrinology 1997, 138:3901-3911.

43. Ke HZ, Foley GL, Simmons HA, Shen V, Thompson DD: Longterm treatment of lasofoxifene preserves bone mass and bone strength and does not adversely affect the uterus in ovariectomized rats. Endocrinology 2004, 145:1996-2005.

44. Gottardis MM, Jordan VC: The antitumor action of keoxifene (raloxifene) and tamoxifen in the $\mathrm{N}$-nitromethylurea-induce rat mammary carcinoma model. Cancer Res 1987, 47:40204024 .
45. Delmas PD, Bjarnason NH, Mitlak BH, Ravoux AC, Shah AS, Huster WJ, Draper M, Christiansen C: Effects of raloxifene on bone mineral density, serum cholesterol concentrations, and uterine endometrium in postmenopausal women. $N$ Engl J Med 1997, 337:1641-1647.

46. Cummings SR, Eckert S, Krueger KA, Grady D, Powles TJ, Cauley JA, Norton L, Nickelsen T, Bjarnason NH, Morrow M, et al.: The effect of raloxifene on risk of breast cancer in postmenopausal women: results from the MORE randomized trial. Multiple Outcomes of Raloxifene Evaluation. JAMA 1999, 281: 2189-2197.

47. Sato $\mathrm{M}$, Turner $\mathrm{CH}$, Wang $\mathrm{T}$, Adrian MD, Rowley $\mathrm{E}$, Bryant $\mathrm{HU}$ : LY353381. HCl: a novel raloxifene analog with improved SERM potency and efficacy in vivo. J Pharmacol Exp Ther 1998, 287: 1-7.

48. Detre S, Riddler S, Salter J, A'Hern R, Dowsett M, Johnston SR: Comparison of the selective estrogen receptor modulator arzoxifene (LY353381) with tamoxifen on tumor growth and biomarker expression in an MCF-7 human breast cancer xenograft model. Cancer Res 2003, 63:6516-6522.

49. Rowley $\mathrm{E}$, Adrian MD, Bryant $\mathrm{H}$, et al:: The new SERM LY353381.HCL has advantages over estrogen, tamoxifen, and raloxifene in reproductive and non-reproductive tissues of aged ovariectomised rats. Proc Am Soc Bone Min Res 1997:A490.

50. Baselga J, Llombart-Cussac A, Bellet M, Guillem-Porta V, Enas N, Krejcy K, Carrasco E, Kayitalire L, Kuta M, Lluch A, et al.: Randomized, double-blind, multicenter trial comparing two doses of arzoxifene (LY353381) in hormone-sensitive advanced or metastatic breast cancer patients. Ann Oncol 2003, 14:13831390.

51. Buzdar A, O'Shaughnessy JA, Booser DJ, Pippen JE Jr, Jones SE, Munster PN, Peterson P, Melemed AS, Winer E, Hudis C: Phase II, randomized, double-blind study of two dose levels of arzoxifene in patients with locally advanced or metastatic breast cancer. J Clin Oncol 2003, 21:1007-1014.

52. Labrie F, Labrie C, Belanger A, Simard J, Gauthier S, Luu-The V Merand Y, Giguere V, Candas B, Luo S, et al.: EM-652 (SCH 57068), a third generation SERM acting as pure antiestrogen in the mammary gland and endometrium. $J$ Steroid Biochem Mol Biol 1999, 69:51-84.

53. Simard J, Labrie C, Belanger A, Gauthier S, Singh SM, Merand Y, Labrie F: Characterization of the effects of the novel nonsteroidal antiestrogen EM-800 on basal and estrogen-induced proliferation of T-47D, ZR-75-1 and MCF-7 human breast cancer cells in vitro. Int J Cancer 1997, 73:104-112.

54. Johnston SRD, Detre S, Riddler S, Dowsett M: SCH 57068 is a selective estrogen receptor modulator (SERM) without uterotrophic effects compared with either tamoxifen or raloxifene. Breast Cancer Res Treat 2000, Dec 2000:A163.

55. Gutman M, Couillard S, Roy J, Labrie F, Candas B, Labrie C: Comparison of the effects of EM-652 (SCH57068), tamoxifen, toremifene, droloxifene, idoxifene, GW-5638 and raloxifene on the growth of human ZR-75-1 breast tumors in nude mice. Int $J$ Cancer 2002, 99:273-278.

56. Roy J, Couillard S, Gutman M, Labrie F: A novel pure SERM achieves complete regression of the majority of human breast cancer tumors in nude mice. Breast Cancer Res Treat 2003, 81:223-229.

57. Luo S, Martel C, Sourla A, Gauthier S, Merand Y, Belanger A, Labrie C, Labrie F: Comparative effects of 28-day treatment with the new anti-estrogen EM-800 and tamoxifen on estrogen-sensitive parameters in intact mice. Int J Cancer 1997, 73: 381-391.

58. Martel C, Picard S, Richard V, Belanger A, Labrie C, Labrie F: Prevention of bone loss by EM-800 and raloxifene in the ovariectomized rat. J Steroid Biochem Mol Biol 2000, 74:45-56.

59. Labrie F, Champagne P, Labrie C, Roy J, Laverdiere J, Provencher L, Potvin M, Drolet Y, Pollak M, Panasci L, et al:: Activity and safety of the antiestrogen EM-800, the orally active precursor of acolbifene, in tamoxifen-resistant breast cancer. J Clin Oncol 2004, 22:864-871.

60. von Angerer E, Prekajac J, Strohmeier J: 2-Phenylindoles. Relationship between structure, estrogen receptor affinity, and mammary tumor inhibiting activity in the rat. $J$ Med Chem 1984, 27:1439-1447.

61. Stein RC, Dowsett M, Cunningham DC, Davenport J, Ford HT, Gazet JC, von Angerer E, Coombes RC: Phase I/II study of the 
anti-oestrogen zindoxifene (D16726) in the treatment of advanced breast cancer. A Cancer Research Campaign Phase I/II Clinical Trials Committee study. Br J Cancer 1990, 61:451453.

62. Miller CP, Collini MD, Tran BD, Harris HA, Kharode YP, Marzolf JT, Moran RA, Henderson RA, Bender RH, Unwalla RJ, et al.: Design, synthesis, and preclinical characterization of novel, highly selective indole estrogens. J Med Chem 2001, 44:16541657.

63. Greenberger LM, Annable T, Collins KI, Komm BS, Lyttle CR, Miller CP, Satyaswaroop PG, Zhang Y, Frost P: A new antiestrogen, 2-(4-hydroxy-phenyl)-3-methyl-1-[4-(2-piperidin-1yl-ethoxy)-benzyl]-1H-in dol-5-ol hydrochloride (ERA-923), inhibits the growth of tamoxifen-sensitive and -resistant tumors and is devoid of uterotropic effects in mice and rats. Clin Cancer Res 2001, 7:3166-3177.

64. Cotreau MM, Stonis L, Dykstra KH, Gandhi T, Gutierrez M, Xu J, Park Y, Burghart PH, Schwertschlag US: Multiple-dose, safety, pharmacokinetics, and pharmacodynamics of a new selective estrogen receptor modulator, ERA-923, in healthy postmenopausal women. J Clin Pharmacol 2002, 42:157-165.

65. Cauley JA, Norton L, Lippman ME, Eckert S, Krueger KA, Purdie DW, Farrerons J, Karasik A, Mellstrom D, Ng KW, et al.: Continued breast cancer risk reduction in postmenopausal women treated with raloxifene: 4-year results from the MORE trial. Multiple outcomes of raloxifene evaluation. Breast Cancer Res Treat 2001, 65:125-134.

66. Vogel VG, Costantino JP, Wickerham DL, Cronin WM: National surgical adjuvant breast and bowel project update: prevention trials and endocrine therapy of ductal carcinoma in situ. Clin Cancer Res 2003, 9:495S-501S

67. Chang J, Powles TJ, Allred DC, Ashley SE, Makris A, Gregory RK, Osborne CK, Dowsett M: Prediction of clinical outcome from primary tamoxifen by expression of biologic markers in breast cancer patients. Clin Cancer Res 2000, 6:616-621.

68. Dowsett M, Smith IE, Ebbs SR, Dixon JM, Skene A, Griffith C, Boeddinghaus I, Salter J, Detre S, Hills M, et al.: Short-term changes in Ki-67 during neoadjuvant treatment of primary breast cancer with anastrozole or tamoxifen alone or combined correlate with recurrence-free survival. Clin Cancer Res 2005, 11:951s-958s.

69. Howell A, Cuzick J, Baum M, Buzdar A, Dowsett M, Forbes JF, Hoctin-Boes G, Houghton J, Locker GY, Tobias JS: Results of the ATAC (Arimidex, Tamoxifen, Alone or in Combination) trial after completion of 5 years' adjuvant treatment for breast cancer. Lancet 2005, 365:60-62.

70. Decensi A, Robertson $C$, Viale $G$, Pigatto $F$, Johansson $H$, Kisanga ER, Veronesi P, Torrisi R, Cazzaniga M, Mora S, et al.: A randomized trial of low-dose tamoxifen on breast cancer proliferation and blood estrogenic biomarkers. J Natl Cancer Inst 2003, 95:779-790

71. Dowsett M, Dixon JM, Horgan K, Salter J, Hills M, Harvey E: Antiproliferative effects of idoxifene in a placebo-controlled trial in primary human breast cancer. Clin Cancer Res 2000, 6: 2260-2267.

72. Dowsett M, Bundred NJ, Decensi A, Sainsbury RC, Lu Y, Hills MJ, Cohen FJ, Veronesi P, O'Brien ME, Scott T, et al.: Effect of raloxifene on breast cancer cell Ki67 and apoptosis: a doubleblind, placebo-controlled, randomized clinical trial in postmenopausal patients. Cancer Epidemiol Biomarkers Prev 2001, 10:961-966

73. Fabian CJ, Kimler BF, Anderson J, Tawfik OW, Mayo MS, Burak WE Jr, O'Shaughnessy JA, Albain KS, Hyams DM, Budd GT, et al.: Breast cancer chemoprevention phase I evaluation of biomarker modulation by arzoxifene, a third generation selective estrogen receptor modulator. Clin Cancer Res 2004, 10:54035417

74. Luo S, Labrie C, Belanger A, Candas B, Labrie F: Prevention of development of dimethylbenz(a)anthracene (DMBA)-induced mammary tumors in the rat by the new nonsteroidal antiestrogen EM-800 (SCH57050). Breast Cancer Res Treat 1998, 49:111.

75. Suh N, Glasebrook AL, Palkowitz AD, Bryant HU, Burris LL, Starling JJ, Pearce HL, Williams C, Peer C, Wang Y, et al:: Arzoxifene, a new selective estrogen receptor modulator for chemoprevention of experimental breast cancer. Cancer Res 2001, 61:8412-8415.
76. Parker MG: Action of 'pure' antiestrogens in inhibiting estrogen receptor action. Breast Cancer Res Treat 1993, 26:131137.

77. Pink JJ, Jordan VC: Models of estrogen receptor regulation by estrogens and antiestrogens in breast cancer cell lines. Cancer Res 1996, 56:2321-2330.

78. Howell A, Osborne CK, Morris C, Wakeling AE: ICI 182,780 (Faslodex): development of a novel, 'pure' antiestrogen. Cancer 2000, 89:817-825.

79. Hu XF, Veroni M, De Luise M, Wakeling A, Sutherland R, Watts CK, Zalcberg JR: Circumvention of tamoxifen resistance by the pure anti-estrogen ICI 182,780. Int J Cancer 1993, 55:873-876.

80. Osborne CK, Coronado-Heinsohn EB, Hilsenbeck SG, McCue BL, Wakeling AE, McClelland RA, Manning DL, Nicholson RI: Comparison of the effects of a pure steroidal antiestrogen with those of tamoxifen in a model of human breast cancer. $J$ Natl Cancer Inst 1995, 87:746-750.

81. Robertson JF, Nicholson RI, Bundred NJ, Anderson E, Rayter Z, Dowsett M, Fox JN, Gee JM, Webster A, Wakeling AE, et al: Comparison of the short-term biological effects of 7alpha-[9(4,4,5,5,5-pentafluoropentylsulfinyl)-nonyl]estra-1,3,5, (10)-triene3,17 beta-diol (Faslodex) versus tamoxifen in postmenopausal women with primary breast cancer. Cancer Res 2001, 61:6739-6746.

82. Howell A, DeFriend DJ, Robertson JF, Blamey RW, Anderson L, Anderson E, Sutcliffe FA, Walton P: Pharmacokinetics, pharmacological and anti-tumour effects of the specific anti-oestrogen $\mathrm{ICl} 182780$ in women with advanced breast cancer. $\mathrm{Br} J$ Cancer 1996, 74:300-308.

83. Howell A, DeFriend D, Robertson J, Blamey R, Walton $P$ : Response to a specific antioestrogen (ICl 182780) in tamoxifen-resistant breast cancer. Lancet 1995, 345:29-30.

84. Osborne CK, Pippen J, Jones SE, Parker LM, Ellis M, Come S, Gertler SZ, May JT, Burton G, Dimery I, et al.: Double-blind, randomized trial comparing the efficacy and tolerability of fulvestrant versus anastrozole in postmenopausal women with advanced breast cancer progressing on prior endocrine therapy: results of a North American trial. J Clin Oncol 2002, 20:3386-3395.

85. Howell A, Robertson JF, Quaresma Albano J, Aschermannova A, Mauriac L, Kleeberg UR, Vergote I, Erikstein B, Webster A, Morris C: Fulvestrant, formerly ICl 182,780 , is as effective as anastrozole in postmenopausal women with advanced breast cancer progressing after prior endocrine treatment. J Clin Oncol 2002, 20:3396-3403.

86. Howell A, Robertson JF, Abram P, Lichinitser MR, Elledge R, Bajetta E, Watanabe T, Morris C, Webster A, Dimery I, et al.: Comparison of fulvestrant versus tamoxifen for the treatment of advanced breast cancer in postmenopausal women previously untreated with endocrine therapy: a multinational, double-blind, randomized trial. J Clin Oncol 2004, 22:16051613.

87. Erikstein B, Robertson JFR, Osborne CK, Pippen J, Harrison M: ICl 182,780 ('Faslodex') 250 mg monthly intramuscular (IM) injection shows consistent PK profile when given as either $1 \times 5 \mathrm{ml}$ or $2 \times 2.5 \mathrm{ml}$ injections in postmenopausal women with advanced breast cancer (ABC). Proc Am Soc Clin Oncol 2001, 20:A2025.

88. Martin LA, Farmer I, Johnston SR, Ali S, Marshall C, Dowsett M: Enhanced estrogen receptor (ER) alpha, ERBB2, and MAPK signal transduction pathways operate during the adaptation of MCF-7 cells to long term estrogen deprivation. $J$ Biol Chem 2003, 278:30458-30468.

89. Jeng MH, Shupnik MA, Bender TP, Westin EH, Bandyopadhyay D, Kumar R, Masamura S, Santen RJ: Estrogen receptor expression and function in long-term estrogen-deprived human breast cancer cells. Endocrinology 1998, 139:4164-4174.

90. Long BJ, Jelovac D, Thiantanawat A, Brodie AM: The effect of second-line antiestrogen therapy on breast tumor growth after first-line treatment with the aromatase inhibitor letrozole: long-term studies using the intratumoral aromatase postmenopausal breast cancer model. Clin Cancer Res 2002, 8:2378-2388.

91. Franco S, Perez A, Tan-Chiu E, Frankel C, Vogel CL: Fulvestrant demonstrates clinical benefit in heavily pre-treated postmenopausal women with advanced breast cancer. Breast Cancer Res Treat 2003, 82:S105. 
92. Ingle JN, Rowland KM, Suman VJ, Mirchandani D, Bernath AM, Camoriano JK, Perez EA: Evaluation of fulvestrant in women with advanced breast cancer and progression on prior aromatase inhibitor therapy: a phase II trial of the North Central Cancer Treatment Group. Breast Cancer Res Treat 2004, 88: S38.

93. Perey L, Paridaens R, Nole F, Pagani O, Bonnefoi H, Aebi S, Dietrich D, Goldhirsch A, Thurlimann B: Fulvestrant as hormonal treatment in postmenopausal women with advanced breast cancer progressing after treatment with tamoxifen and aromatase inhibitors: update of a phase II SAKK trial. Breast Cancer Res Treat 2004, 18:S236.

94. Petruzelka L, Zimovjanova M: Fulvestrant in postmenopausal women with metastatic breast cancer progressing on prior endocrine therapy: results from an expanded access programme. Eur J Cancer 2004, 132:A264

95. Steger GG, Bartsch R, Wenzel C, Pluschnig U, Locker G, Mader RM, Zielinksi CC: Fulvestrant beyond the second hormonal treatment line in metastatic breast cancer. Proc $\mathrm{Am}$ Soc Clin Oncol 2003, 22:A20.

96. Johnston S: Fulvestrant and the sequential endocrine cascade for advanced breast cancer. Br J Cancer 2004, Suppl 1:S15S18. 